A very short inquiry would have shown that this remark could not stand. Śaka 1021 expired (as most usually cited) was certainly A.D. 1099 (in the sense that the first ten months of that Saka year fell in A.D. 1099), but the cyclic year was Pramāthin: Bahudhānya was Śaka 1021 current, corresponding, in the sense stated above, to A.D. 1098 (not 1099).

These discrepancies do not affect Mr. Narasimhiengar's present results. But attention is drawn to them to illustrate further the point (compare p. 149 above) that anyone who aims at dealing with chronological matters, and wishes to inspire confidence in his results, must first get all his dates properly settled, so that they will stand being checked by his readers.

A remark may be added about the final date, No. 9. The record, vol. 12, Ck. 28, is dated in the Dhatu samvatsara, Saka 1079. This, again, is a current Śaka year: and in this case the equivalent is given rightly as " 1156 A.D." at trans. p. 80. The text shows (p. 136) that the record seems to have been dated on the day of the winter solstice. If so, it takes Vishnuvardhana on to quite the end of A.D. 1156.

J. F. F.

\title{
MR. MARSHALL'S TAXILA INSCRIPTION
}

Having now, by the courtesy of Mr. Marshall, been favoured with a copy of the new inscription, I may be allowed to add the following observations, which are partly of an apologetic character :-

1. First, I may venture to express a high appreciation of the great exactness of the reading, which leaves practically nothing to reward the scrutiny of other scholars. The photograph itself is a remarkable technical achievement, being pieced together out of as many as sixteen fragments. 
2. The reading pradistavita, for which I had proposed pratithavita, is in both instances quite certain. The form, being undoubtedly an equivalent of pratithavita = pratisthapita, must be regarded as a characteristic of the local dialect.

3. Inspection seems to confirm the readings $U$ (rasi)kena (11. 1-2), Intaphria (1. 2), proposed by me; in the case of (ni)rva(nae) also, for $(m) a(n a e)$, the curve in the $a$ is favourable (Mr. Marshall, I learn, does not assent).

4. (Sa) dhiham $(n \alpha)$ and $\alpha$. de (in 1. 5) are still obscure. We expect the inscription to end ayam deya-dharmaparicăgo, which may have been wrongly copied by the (rather careless) workman.

5. In pracega (l. 4) the vowel $e$ seems to be indicated.

6. The important ayasa (in 1. 1) appears to stand good. Whether the viyasa, which has been proposed by Dr. Fleet (October, 1914, pp. 998-9) and against which I have no prejudice (except, perhaps, on grounds of date and dialect), may possibly be read, I am unable to decide (Mr. Marshall is certain of ayasa).

F. W. Thomas.

\section{LA FONDATION DE GOEJE}

1. Le conseil de la fondation n'ayant subi aucun changement depuis le mois de novembre 1913, est composé comme suit: MM. C. Snouck Hurgronje (président), H. T. Karsten, M. Th. Houtsma, T. J. de Boer, et C. van Vollenhoven (secrétaire-trésorier).

2. Vers la fin de l'an dernier, le conseil a pris à la charge de la fondation l'édition critique du Kitâb al-Fâkhir d'al-Mufaḍdal par M. C. S. Storey ; elle paraîtra avant peu chez l'éditeur Brill à Leiden.

3. Au printemps le conseil a accordé une subvention au docteur G. Bergsträsser, de Leipzig, en vue d'une enquête sur la langue arabe parlée en Syrie et en 